\title{
Expressão de citocinas na membrana sinovial e sua relação com a concentração sinovial na osteocondrite dissecante $(O C D)$ e osteoartrite $(O A)$ em equinos
}

Fernanda Rodrigues Agreste; Joice Fülber, Juliana Junqueira Moreira, Sarah Raphaela Torquato Seidel, Cynthia do Prado Vendrusculo, Lucas Martins Chaible, Luis Cláudio Lopes Correia da Silva, Raquel Yvonne Arantes Baccarin

*Autor correspondente

e-mail: fe_nandara@hotmail.com

\section{Resumo}

A osteoartrite $(\mathrm{OA})$ e a osteocondrite dissecante (OCD) estão entre as principais afecções que acometem os equinos atletas. A utilização de antagonistas naturais ou análogos sintéticos que impeçam a progressão do processo degenerativo e que atuem na recuperação desta homeostase vem sendo cada vez mais discutida. Com isso, o entendimento da cascata de eventos inflamatórios e degenerativos articulares nos diferentes estágios das doenças articulares é imprescindível para direcionar a melhor abordagem terapêutica, impedindo a progressão da doença e facilitando o estabelecimento de um prognóstico. As citocinas produzidas durante os processos articulares são classificadas como biomarcadores indiretos e suas mensurações são de grande utilidade e interesse, podendo auxiliar no esclarecimento dos processos fisiopatológicos das artropatias, avaliar o grau de degradação da cartilagem articular e monitorar a resposta à terapia, além de possibilitar o estabelecimento de um prognóstico. A participação ativa destes mediadores nos processos inflamatórios altera diretamente a membrana sinovial, cartilagem articular e composição do líquido sinovial. Diante disso, o objetivo desse estudo foi avaliar o perfil da expressão das citocinas pró-inflamatórias (IL-1 $\beta$, IL-6 e TNF $\alpha$ ) e anti-inflamatórias (IL-10), que agem no processo inflamatório na membrana e líquido sinovial de articulações com OA e OCD, comparando com as hígidas. Foram utilizados 34 equinos, sem restrição quanto ao sexo e raça. Deste total, 24 animais foram submetidos a tratamento artroscópico, sendo 12 animais acometidos por osteoartrite (OA) e 12 animais com osteocondrite dissecante (OCD). Outros 10 animais formaram o grupo controle, com articulações hígidas. Amostras do líquido sinovial e membrana foram coletados e armazenados em tubo RNAse free a $-80^{\circ} \mathrm{C}$. A expressão gênica das citocinas (IL-1 $\beta$, IL-6 IL-10) foi avaliada em PCR real time. A dosagem das citocinas IL-1 $\beta$, IL-6 IL-10 e TNF $\alpha$ do líquido sinovial foi realizada segundo a metodologia do ensaio MILLIPLEX MAP Equine Cytokine/Chemokine Panel. Observamos aumento na expressão do gene IL-1ß, IL-10 nos grupos OCD e OA; já a IL-6 aumentou a expressão no grupo 
OCD e diminui no grupo OA, quando comparados com o grupo controle. Pela expressão da proteína, houve aumento na concentração de IL-1 $\beta$ e IL-6 (4,00 $\pm 1,53 ; 32,02 \pm 49,16$ pg/mL respectivamente) e diminuição na concentração de IL-10 (29,71 $\pm 16,13 \mathrm{pg} / \mathrm{mL})$ no grupo OA em relação ao OCD (IL-1 = 3,21 \pm 2 ,10; IL-6 $=2,12 \pm 0,68$; IL-10 = 43,29 $\pm 21,90 \mathrm{pg} / \mathrm{mL}$ ) e controle (IL-1 = 2,69 $\pm 1,02 ;$ IL-6 = 3,04 $\pm 1,94 ;$ IL-10 = $70,12 \pm 57,22 \mathrm{pg} / \mathrm{mL}$ ); já a concentração de TNF $\alpha$ não foi alterada (controle=1,30 $\pm 0,37 ; 0 A=1,19 \pm 0,29$; $\mathrm{OCD}=1,32 \pm 0,41 \mathrm{pg} / \mathrm{mL}$ ). Nossos resultados demonstram que apesar do aumento da expressão de IL-1, IL-6 e IL-10 na membrana sinovial das articulações com OCD, não foi gerado aumento da concentração destas citocinas no líquido sinovial. Contudo, nas articulações com OA, o aumento da expressão de IL-1 se traduziu em aumento na concentração de IL-1 no líquido sinovial, e inesperadamente os resultados de IL-6 e IL-10 apresentaram relação inversa. No acompanhamento dos animais, 85\% do grupo OCD e apenas 25\% do grupo $\mathrm{OA}$ retornaram ao treinamento. Este fato sugere que a fase inicial do processo inflamatório pode não trazer alterações estruturais na cartilagem nos casos da OCD, e sua progressão pode ser modulada pela intensidade de treinamento e conduta terapêutica adequada. Já a avaliação dos biomarcadores na membrana e líquido sinovial nos casos de OA mostrou um perfil mais inflamatório do que a OCD, e reflete uma evolução progressiva e variável da doença articular até sua fase final, justificado pela diversidade de valores na expressão e concentrações de citocinas. A avaliação de biomarcadores na rotina clínica pode monitorar a progressão da OA e classificá-la, oferecendo prognóstico mais acurado.

Palavras-chave: Osteoartrite. Osteocondrite. Citocinas.

Agradecimentos: à Fapesp. 